Revista Eletrônica Geografar, Curitiba, v. 2, Resumos do VI Seminário Interno de Pós-Graduação em Geografia, p. 48-48. Junho/2007

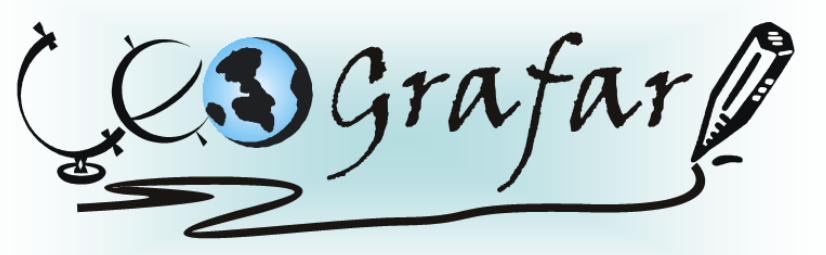

Revista Eletrônica do Programa de Pós-Graduação em Geografia - UFPR

\title{
A ESTÉTICA TURÍSTICA DAS CIDADES LITORÂNEAS DO PARANÁ
}

\author{
MARCELO CHEMIN ${ }^{1}$
}

Espaços turísticos, segundo Boullón e Yázigi, definem-se pela presença e distribuição de atrativos turísticos como paisagens. Assim, configura-se como territorialidade e condição espacial a "estética" como um elemento fundamental de uma rede de territórios direcionados à estadia, lazer e interação social na sua organização funcional e infraestrutura. Esta pesquisa objetiva analisar a função da estética e a sua interligação com a composição funcional da paisagem das cidades do litoral do Paraná. A sua base empírica é o conjunto das sete cidades litorâneas do Paraná: Guaratuba, Matinhos, Pontal do Paraná, Paranaguá, Morretes, Antonina e Guaraqueçaba. As três primeiras cidades são balneários consagrados e as quatro outras possuem especial relevância histórica no processo de ocupação do Paraná e sul do Brasil. O zoneamento turístico do Paraná confere ao litoral o status de região turística, seguindo critérios da Política Nacional de Turismo. A luz da geografia humanística e com aporte teórico na fenomenologia, a paisagem urbana apresenta-se como um lugar, onde turistas e moradores procuram como expressão sóciocultural experiências estéticas e representações simbólicas, que seguem os seus respectivos sentimentos, valores e significados sociais. Assim, a composição estética confere atratividade turística ao encontro entre estéticas de diferentes grupos sociais. Para isso, projeta-se uma pesquisa de campo que fará uma análise exploratório-descritiva. Se utilizará como técnica a observação através do registro fotográfico. Trata-se, assim, da tentativa de se constituir uma ferramenta de planejamento urbano e turístico que entenda como a qualidade do ambiente pode favorecer um encontro intercultural entre moradores e turistas.

Palavras-Chave: Paisagem Urbana, Estética, Litoral do Paraná

1Doutorando em Geografia - UFPR - email: marcelochemin@ufpr.br Orientadora: CICILIAN LUIZA LÖWEN SAHR 